\title{
A never requested triumph? Reframing gender boundaries in Fiume and Sušak after 1918*
}

\author{
Francesca Rolandi**
}

The First World War unsettled not just the geopolitical arrangement of a large part of Europe, but also previously held gender roles and family relations. With the conflict's end, the bordering cities of Fiume and Sušak went through a long transition characterised by administrative instability and economic uncertainty, as well as by political and national tensions, before being integrated into the Kingdom of Italy and the Kingdom of Serbs, Croats and Slovenes, respectively.

Drawing on available sources in both Italian and Croatian, this article analyses the case study of a border area in order to investigate women's presence in the public sphere, considering both their political participation - to the extent this was allowed by the different forms of suffrage - and their associationism within political and philanthropic organisations. Moreover, in order to trace the reactions triggered by women's activism, the article examines gender representations in the local press, which was mostly linked to the main conflicting political factions and dominated by male journalists.

Key words: Upper Adriatic, Gender, Post-WW1, Politics, Representations

In 1919 the Italian-language newspaper of Fiume, La Vedetta d'Italia, published an article about a new clothing item: the pyjama. Instead of focusing on matters of fashion and style, the article engaged in a wider discussion about women's role in contemporary society:

In these recent times without strikes, without protests, it cannot be denied that woman has made great progress. Through facts, rather than through words, she has given proof of her hugely versatile talent. She has invaded factories, warehouses, court rooms, hospitals, laboratories, offices of every kind, and soon she will move, with admiral ease, from the marital room to that of the members of parliament, spreading the gay notes of her femininity every-

* This article was written as part of the project EIRENE (Post-war transitions in gendered perspective: the case of the North-Eastern Adriatic region), funded by the European Research Council as part of the Advanced Grant funding scheme Horizon 2020 [ERC Grant Agreement n. 742683].

** University of Ljubljana (Univerza v Ljubljani); francesca.rolandi@gmail.com 
where she goes. There is, then, a tendency that she masculinises herself, but only so much. In the meantime, within the domestic walls, in the secrecy of her bedroom, she has started to wear a nightly clothing item that brings her very close to man: the pyjama. ${ }^{1}$

As the article frivolously suggested, the women of Fiume had conquered a significant presence in the workplace, in educational institutions and in spaces of sociability, and they seemed ready to burst onto the political scene as well. Yet, their path towards inclusion in the public sphere and political representation - which seemed consolidated during the first months of post-war enthusiasm - would prove to be far more complicated and ridden with contradiction. Also, gender representations that would be radically affected by the reshuffling of roles during the war oscillated between the expectations of the first post-war years and the adjustment to more traditional views, which gained traction over the years.

Starting from a historiographical overview of the first post-war period in Fiume, with particular attention being paid to gender narratives, this article aims to examine women's participation made possible by different forms of suffrage, not to mention by their activism within political organisations and philanthropic associations. Moreover, in order to trace contemporary reactions to women's engagement, I will analyse gender representations in the local press, which were mostly conveyed by male voices.

The article focuses on the neighbouring cities of Fiume and Sušak. In the second post-war period, these were merged into the present city of Fiume/ Rijeka. In the Austro-Hungarian Empire, Fiume was a corpus separatum that depended directly on the Hungarian government, whereas Sušak belonged to the Kingdom of Croatia-Slavonia, also dependent on the Hungarian crown. Although the two cities also differed in terms of identity, with a much stronger Italian-speaking presence in the former and a Croatian-speaking majority in the latter, they developed thanks to a relationship of proximity and interdependence, which persisted after the dissolution of the Habsburg Empire. In 1918, the Italian National Council (Consiglio Nazionale Italiano, hereafter CNI) seized power in Fiume, which had not been included among the claims foreseen by the Treaty of London. The CNI supported Fiume's annexation to Italy - a claim the irredentist poet Gabriele D'Annunzio had also made his own. Thus, in September 1919, D'Annunzio marched into Fiume with military troops and ruled the city - together with municipal authorities - until December 1920, when the Italian army forced him out in view of the Treaty of Rapallo that had been agreed with the Kingdom of Serbs, Croats and Slovenes (hereafter SCS), which established the Free State of Fiume. A situation of continued instability, generated by local as well as foreign nationalists and fascists, obstructed the functioning of the small state, even if it was interna-

${ }^{1}$ La moda, "La Vedetta d'Italia" (hereafter "VI"), 29 August 1919, p. 3. 
tionally recognised. It was eventually annexed to Italy via the establishment of transitory authorities. The neighbouring city of Sušak, on the other hand, was the propulsive centre of pro-Yugoslav nationalism. It passed the first post-war years under Italian occupation before it fell under the sovereignty of the nearby Kingdom of SCS in 1923.

My analysis focuses on the long transition period following the First World War, and draws on a range of local press outlets - both in Italian and Croatian - that represented the main political factions vying for control over the city: the press that supported Fiume's annexation to Italy and, accordingly, D'Annunzio's expedition; the pro-Yugoslav press, which instead sustained the annexation of Fiume as well as Sušak to the nascent Kingdom of SCS; the autonomist press, which advocated the creation of a Free State of Fiume, drawing on a culturally Italian urban identity that - after 1919, also in opposition to Fascism - was increasingly viewed from a supranational perspective. ${ }^{2}$ Given that Fiume's Socialist and Communist parties left only few traces in the period under examination, both in terms of press sources and archival material, I have not been able to include these political sectors into my analysis. It is nonetheless certain that they supported women's suffrage; for example, after 1921 there had been a Women's section of the Communist Party of Fiume. ${ }^{3}$

Over the last years, new scholarly research has studied the unique history of Fiume during the entire twentieth century, paying particular attention to the post-war periods, ${ }^{4}$ to the formation of national and political identities, ${ }^{5}$ and to the continuities and divisions that marked the crisis of Fiume during the dissolution of the Habsburg Empire. ${ }^{6}$

Fiume acquired both international and national fame during the first postwar period, when the city — claimed by competing irredentists — became

${ }^{2}$ Due to the repressive actions against the press that opposed the joint rule of the CNI and D'Annunzio's entourage, the autonomist and pro-Yugoslav newspapers were published irregularly. Consequently, they are available in smaller numbers as opposed to the pro-annexation newspapers.

${ }^{3}$ Mihael Sobolevski, Luciano Giuricin, Il Partito comunista di Fiume 1921-1924, Rijeka, Centar za historiju radnickog pokreta i NOR-a Istre, Hrvatskog primorja i Gorskog kotara; Rovigno, Centro di ricerche storiche dell'Unione degli italiani dell'Istria e di Fiume, 1981, pp. 184, 246-249.

${ }^{4}$ William Klinger, Un'altra Italia: Fiume 1724-1924, Trieste, Lega nazionale; Rovigno, Centro di ricerche storiche, 2018; Andrea Roknić Bežanić, Uspostava i organizacija civilnih $i$ vojnih vlasti u poslijeratnoj Rijeci, "Časopis za povijest Zapadne Hrvatske”, 2011/2012, n. 6/7, pp. 163-177.

${ }^{5}$ Ivan Jelićić, The typographers' community of Fiume: combining a spirit of collegiality, class identity, local patriotism, socialism, and nationalism(s), "Austrian History Yearbook", 2018, pp. 73-86; Marco Abram, Integrating Rijeka into socialist Yugoslavia: the politics of national identity and the new city's image (1947-1955), "Nationality papers", 2018, n. 1, pp. 69-85.

${ }^{6}$ Dominique K. Reill, Post-Imperial Europe: when comparison threatened, empowered, and was omnipresent, "Slavic review", 2019, n. 3, pp. 663-670; Dominique K. Reill, The Fiume crisis: life in the wake of the Habsburg Empire, Belknap-Cambridge MA, Harvard University Press, 2020. 
one of the sources of contention in the Paris peace negotiations. This time of political tension culminated in Gabriele D'Annunzio's expedition, and he would maintain control over the Kvarner city for more than 15 months. Throughout the decades, numerous Italian-language studies have been dedicated to this political phase, ${ }^{7}$ often focusing on its diplomatic history or on the political meaning of 'fiumianism'. Croatian historiography has revisited the entire incident paying specific attention to the urban centre of $\mathrm{Sušak}^{8}$ as well as to the theme of national persecutions against the Croats in Fiume, highlighting the continuity between D'Annunzio's actions and Fascism. ${ }^{9}$

A vast amount of both Italian and Croatian literature has approached national identities as eternal and unchanging elements, which can be revived or suppressed. This perspective contrasts with new historiographical studies of the post-Habsburg area that have analysed processes of national construction from an increasingly critical viewpoint. ${ }^{10}$ Although the predominantly nation-centred perspective has contributed to convey a narrative focused exclusively on the conflict between Italians and Croats, there are also studies that have analysed the multiplicity of identities within these formations as well as actors that cannot be placed on any side of the dichotomy. ${ }^{11}$

Moreover, some of the more recent studies have highlighted how the insurrection of sections of the national army that followed D'Annunzio to Fiume affected the fragile political balances in Italy. ${ }^{12}$ Due to the dual focus on political events and the construction of the "poet-soldier" myth, and on the conse-

${ }^{7}$ For an overview of Italian historiography on this period see Francesco Perfetti, D'Annunzio e l'impresa di Fiume. Un bilancio storiografico, in Melita Sciucca (ed.), Fiume nel secolo dei grandi mutamenti / Rijeka u stoljeću velikih promjena, Fiume = Rijeka, Edit, 2001; Antonella Ercolani, Da Fiume a Rijeka: profilo storico-politico dal 1918 al 1947, Soveria Mannelli, Rubbettino, 2009; Giovanni Stelli, Storia di Fiume: dalle origini ai giorni nostri, Pordenone, Biblioteca dell'immagine, 2017; Raoul Pupo, Fiume città di passione, Rome-Bari, Laterza, 2018.

${ }_{8}$ Željko Bartulović, Sušak 1919.-1947.: državnopravni položaj grada, Rijeka, Adamić Državni arhiv Rijeka - Pravni fakultet, 2004.

${ }^{9}$ For an overview of relevant Croatian historiography see Mihael Sobolevski, D’Annunzijeva vladavina u Rijeci (rujan 1919. - siječanj 1921.) - Prvi egzodus hrvata in Marino Manin (ed.), Talijanska uprava i egzodus Hrvata 1918.-1943. Zbornik radova sa Međunarodnog skupa, Zagreb: Hrvatski institut za povijest - Društvo Egzodus istarskih Hrvata, 2001, p. 287. See also Daniel Patafta, Promjene u nacionalnoj strukturi stanovništva grada Rijeke od 1918. do 1924. godine, "Časopis za suvremenu povijest", 2004, n. 2, pp. 683-700. For an analysis of women's conditions see Tea Perinčić Mayhew, Rijeka ili smrt: D’Annunzijeva okupacija Rijeke 1919.1921. - Rijeka or death! D'Annunzio's occupation of Rijeka 1919-1921, Rijeka, Naklada Val Maritime and History Museum of the Croatian Littoral - Rijeka EPK 2020, 2019.

${ }^{10}$ Borut Klabjan (ed.), Borderlands of memory. Adriatic and Central European perspectives, Oxford, Peter Lang, 2019; see also the 2018 special issue of the "Austrian History Yearbook".

${ }^{11}$ Ljubinka Toševa-Karpowicz, Masonerija, politika i Rijeka (1785.-1944.), Rijeka, Državni arhiv u Rijeci, 2015; I. Jelićić, The typographers' community of Fiume; D.K. Reill, The Fiume crisis.

${ }^{12}$ Marco Mondini, Fiume 1919: una guerra civile italiana, Rome, Salerno, 2019; Enrico Serventi Longhi, Il faro del mondo nuovo: D’Annunzio e i legionari a Fiume fra guerra e rivoluzione, Udine, Gaspari, 2019. 
quences of local political theorisations for Italy, studies of Fiume have often evoked an image of the city that corresponds to its external perception and imagination by those thousands of individuals that flocked to the city, rather than analysing the impact of international events on the fabric of local society.

Next, the emphasis on the uniqueness of the Fiume experience has led certain scholars to separate the city's history from that of the surrounding areas and, with only few exceptions, ${ }^{13}$ to ignore the continuities that linked the D'Annunzian interval (September 1919 - December 1920) to preceding or successive periods. Furthermore, scholarly interest in the political experiment that D'Annunzio embodied - especially the Italian Regency of Carnaro, proclaimed in September 1920 but never applied, which combined typical elements of right-wing political culture and revolutionary trade unionism has resulted in the overlapping of political proclamations and actual measures that were implemented in the city.

Another strand of literature has ascribed a politics of female emancipation to D'Annunzio, drawing on an interpretation of the "Endeavour" of Fiume in "libertarian" terms. ${ }^{14}$ Thanks to an often uncritical analysis of memorial texts published by the soldiers that were stationed in Fiume in subsequent years, ${ }^{15}$ similar studies have helped to convey the image of an orgiastic atmosphere, which supposedly also involved the local population in a triumph of experimentations that is said to have pervaded all spheres of society: from the social order to sexual norms, up to the point that it allegedly anticipated a rebellion against morality comparable to that of 1968. While this comparison may sound out of date, it can be useful to place the incident of Fiume in a contemporary context. As a wide range of studies have stressed, in various European countries many women had come to the conclusion that they could claim a space in the public sphere, especially in Central Europe, where the dissolution of the Austro-Hungarian Empire and the creation of new states seemed favourable to new forms of inclusion..$^{16}$ At the same time, recent scholarship has highlighted the fact that the glorification of masculinity and practices considered deviant from bourgeois morality (e.g. drug abuse, homosexuality or going to brothels) was relatively widespread during and after the First World War, whereas the climate of normalisation during Fascism gradually marginalised and criminalised these behaviours. ${ }^{17}$

${ }^{13}$ D.K. Reill, Post-Imperial Europe; Danilo L. Massagrande, Italia e Fiume: 1921-1924. Dal Natale di sangue all'annessione, Milan, Cisalpino-Goliardica, 1982.

${ }^{14}$ Michael L. Leeden, D’Annunzio a Fiume, Rome-Bari, Laterza, 1975, pp. 140-142; Claudia Salaris, Alla festa della rivoluzione. Artisti e libertari con D’Annunzio a Fiume, Bologna, il Mulino, 2002; Giordano Bruno Guerri, Disobbedisco: cinquecento giorni di rivoluzione. Fiume 1919-1920, Milan, Mondadori, 2019

${ }^{15}$ See, for example, Giovanni Comisso, Le mie stagioni, Milan, Garzanti, 1951.

${ }^{16}$ Ingrid Sharp, Matthew Stibbe (eds.), Aftermaths of war: women's movements and female activists 1918-1923, Leiden-Boston, Brill, 2011.

${ }^{17}$ Matteo Millan, The institutionalisation of squadrismo: disciplining paramilitary violence in the Italian fascist dictatorship, "Contemporary European history", 2013, n. 4, p. 44; Ruth 
Many civilians awaited the end of the First World War with mixed feelings of joy, mourning for the losses and hopes for a better future, to be built from the ashes of a useless bloodbath. While the men were at the front, women were often forced to maintain the family unit on their own, whereas the forced distance put interpersonal relations to the test. ${ }^{18}$ When, in the autumn of 1918, various national councils aimed at claiming independence were created across the ex-Habsburg area, from the beginning Fiume revealed itself to be a contested city; thus, a National Council of Serbs, Croats and Slovenes was proclaimed only to be substituted — shortly thereafter - by an Italian National Council.

Following the dissolution of the Austro-Hungarian Empire, both the Croatian and the Italian press testified to the women's zealous participation, as well as to the contradictory promises of inclusion. From 1918 onwards, an inter-allied military occupation corps of Italian, French, American and - for a brief period - Serbian armies was stationed in Fiume. As the inter-allied naval ships approached the city, on the pages of the Croatian-language daily Primorske novine (printed in Sušak) the National Council of Serbs, Croats and Slovenes invited young women to participate in the ceremony and to prepare flags - an invitation that was welcomed with enthusiasm. ${ }^{19}$ According to the newspaper, women of different ages and dressed in the various national costumes took part in an oceanic demonstration of 25,000 people that traversed the city, waving Yugoslav flags and greeting the Italian fleet as allies; they did so to demonstrate the force of the pro-Yugoslav sector as well as the city's willingness to be part and parcel of the future Kingdom of SCS. If the courtesy demonstration for the Italian contingent served to reaffirm the limits of its mandate, the hearts of the pro-Yugoslav women and men in reality beat for the French soldiers, viewed as the real guardians of the nascent state of southern Slavs. A delegation of six Fiumian women visited Captain Georges Edmond Just Durand-Viel on the Touareg ship, and held a brief speech in French, which ended with the following words: "Long live France, our guardian, friend and ally". ${ }^{20}$ Very soon the various armies present in Fiume would reveal their polarisation, with the Italian and French contingents supporting the city's annexation to Italy or the Kingdom of SCS respectively.

Ben-Ghiat, Unmaking the fascist man: masculinity, film and the transition from dictatorship, "Journal of modern Italian studies", 2005, n. 3, pp. 336-365.

${ }^{18}$ In recent decades, international historiography has increasingly focused on the effects of the First World War on the internal front of the involved countries. For a groundbreaking but still valid study see Richard Wall, Jay Winter (eds.), The upheaval of war: family, work and welfare in Europe, 1914-1918, Cambridge, Cambridge University Press, 1988. For a historical synthesis see Heather Jones, As the centenary approaches: the regeneration of First World War historiography, "The Historical journal", 2013, n. 3, pp. 868-870.

${ }^{19}$ Vesnik, "Primorske novine (hereafter PN)", 1 November 1918, p. 3.

${ }^{20}$ Doček talijanske flote, "PN", 5 November 1918, p. 1. 
The first narratives that interpreted women's contribution to the new state of the SCS in emancipatory terms emerged at this stage. Thus, the musician Pavica Julija Kaftanić made an appeal to the women of the nearby isle of Krk (Veglia) where she herself came from, inviting them to answer the call of the fatherland. In doing so, she insisted on the value of education; in fact, it would have come down to intellectual women, in particular female teachers with a national conscience ("you industrious bees"), to organise public lectures, tackle illiteracy and stimulate the thirst for knowledge. ${ }^{21}$

Nevertheless, as women were loudly calling for a participatory space, forces keen on keeping them out of the local political sphere — and not just symbolically - already seemed to be emerging. Indeed, on the same day of the great commemoration, in order to avoid chaos the Primorske novine warned the Women's committee for propaganda not to convene in the National reading room, considered the place par excellence of Croatian - and subsequently Yugoslav - identity in Fiume, where only male committees assembled. Instead, it was invited to gather in the Secundary women's school of Sušak, where the women would have found ample space to dedicate themselves to various forms of female labour. ${ }^{22}$

An even more direct call for women's inclusion marked the pro-Italian sector. From its very genesis, the CNI sought to embed the female question into its political discourse. On 2 November, the Italian-language daily $I l$ Giornale publicly greeted the women who, during the war, had suffered from the internment of their husbands, brothers and fathers, or who had themselves been imprisoned by the Hungarian authorities. ${ }^{23}$ The pro-Italian women also participated in official delegations. When, a few days later, the Italian Admiral Guglielmo Rainer paid a visit to the Filarmonica-Drammatica, the symbolical headquarters of pro-Italian associationism, he met a delegation of prominent members of Fiume's society; this included various women, among whom the irredentist teacher Emma Brentani. ${ }^{24}$ In those first months, local political forces seemed unanimous in supporting women's suffrage. Indeed, among the first to have called for a women's vote there had also been the Socialist Party: even before the war it had fought for universal suffrage, ${ }^{25}$ organising demonstrations with a strong female participation. ${ }^{26}$

${ }^{21}$ Sestrama Jugoslavenkama sa otoka Krka!, "PN", 17 November 1918, p. 2.

${ }^{22}$ Doček talijanske flote.

${ }^{23}$ La seduta di ieri del Consiglio nazionale italiano, "Il Giornale", 2 November 1918, p. 2.

${ }^{24}$ Cronaca. L'ammiraglio Rainer visita la Filarmonica, "Il Giornale", 8 November 1918, p. 18

${ }^{25}$ Ivan Jeličić, Nell'ombra dell'autonomismo. Il movimento socialista a Fiume, 1901-1921, doctoral thesis, Università di Trieste, 2015/2016, pp. 266-278.

${ }^{26}$ Si costituisce il Consiglio degli operai, "Il Giornale", 31 October 1918, p. 2; L'imponente manifestazione operaia, "Il Giornale", 2 November 1918, p. 2. 


\section{The ambiguous narratives of the women's vote}

In Fiume, the plea for women's participation on behalf of sectors close to the CNI became ever more explicit in the following months; "Il Giornale" repeatedly stressed that the Fiumian women had reached such maturity during the political struggle that they could now engage in politics. ${ }^{27}$ Yet, from the start their inclusion seemed to depend on their level of support for the dominant political option. As an article published in the same newspaper stressed, "we have verified that the majority of Fiumian women contributed to the successful outcome of our sacred cause, which does us great honour, but it would be regrettable if this fact were not to be reconfirmed in the current elections". ${ }^{28}$

Gabriele D'Annunzio's entourage also adhered to the plea for women's participation; on 12 September 1919, D'Annunzio had taken hold of the Adriatic city on request of the CNI, while the inter-allied occupation corps had withdrawn, with the exception of the Italian army. In an article written by the journalist Orazio Pedrazzi - D'Annunzio's Head of Press Office - and published in "La Vedetta d'Italia", the daily that increasingly imposed itself as the citizen government's mouthpiece and eventually even surpassed "Il Giornale", Pedrazzi affirmed that women's suffrage was a compensation men had granted women for their patriotic efforts: a "triumph the Fiumian women had obtained without ever having dreamed of invoking it, without having proclaimed or even foreseen it", represented more in terms of religious bliss than political activism. ${ }^{29}$

In those months, women's participation in the pro-D'Annunzio demonstrations was repeatedly recorded both in the local press and in the many images of the time, which show the Fiumian women populating the political spaces of the masses. Yet, if the cause of Fiume mobilised many Italian middle-class women,$^{30}$ the absence of relevant women's associations in Fiume stands out. Similarly, there are no existing accounts by local activists that took part in the political turmoil. The depicted women are usually part of a large mass and rarely identified as proper political subjects, with names and surnames.

On the pages of Primorske novine, which gave voice to a varied sector that put its hopes into the new Kingdom of SCS, considered as a stronghold against Italian imperialism, women's suffrage in Fiume was transformed into a weapon to debase local politics. Enfranchisement was presented as a strategy of a dominant elite aimed at grabbing consensus at the cost even of counting the votes of servants and prostitutes, considered the only women willing to

${ }^{27}$ Il dovere di organizzare le donne, "Il Giornale", 6 August 1919, p. 2.

${ }^{28}$ Sorelle fiumane, "Il Giornale", 21 October 1919, pp. 1-2.

${ }^{29}$ Orazio Pedrazzi, Le donne fiumane, "VI", 7 September 1919, p. 3.

${ }^{30}$ Victoria de Grazia, Le donne nel regime fascista, Venice, Marsilio, 2007, p. 56. 
"soil themselves" with politics. ${ }^{31}$ A violent disapproval of female participation emerges in particular from the Primorske novine's response to Pedrazzi's article-manifest, published before the Italian occupying forces censured the daily for more than two years. The article, deliberately written in Italian and signed "A Fiumian of seven generations", criticised the pro-annexation activists' political passion, accusing them of immorality and stigmatising women's presence outside the domestic sphere:

The Fiumian woman was and is our pride, she, who as a girl was closely watched by her parents, never exhibited herself alone in the street, as a wife she sacrificed her entire life for her family, caring for her husband and children, a faithful companion and friend, she had neither time nor will to wonder about.

And, in response to his Fiumian counterpart:

Go ahead, just admire your women who forget to clothe their children and leave the house, who are not bothered to prepare your meal, as long as they can take the car for a pleasure ride to Čavle, Castua and even Trieste.

The political passions that the female part of Fiume represented were considered a corruptive element, and the author observed that

our honest Fiumian woman does not ruin herself with street politics, she has more sacred duties to fulfil, the family is her place, never will she soil herself by acting the way your women do! ${ }^{32}$

The article culminated in degrading attacks against those women who were engaged in the Italian nationalist cause, denying them any political maturity and accusing them of demanding the return of the Italian grenadiers, ${ }^{33}$ the latter supposedly being the fathers of their illegitimate children.

Nonetheless, the local newspaper's tones of misogynist hysteria seemed to contrast with the considerable activism of local women in women's associationism. In the immediate post-war period, many women in Sušak were engaged in pro-Yugoslav propaganda, giving lectures, gathering funds for care work activities but also claiming more rights. The most notable presence was that of the Democratic Association of Yugoslav Women [Jugoslovensko žensko demokratsko drustvo, hereafter JŽDD], founded in January 1919 in the presence of 250 people, with the aim of

${ }^{31}$ Riječki izbori, "PN", 10 September 1919, p. 1.

${ }^{32}$ Alla Vedetta d'Italia, "PN", 11 September 1919, p. 3.

${ }^{33}$ The grenadiers, who were stationed in the city as part of the Inter-allied occupation corps, were sent away on decision of the Commission the latter had created so as to investigate the bloodshed of July 1919, as they were considered too close to Italian pro-annexation sectors. 
promoting and creating awareness among women of their role in the widest possible sense, in the economy, in politics, in the family, in school, and so on; protecting children and youngsters, especially if in poverty; protecting disabled veterans from decline ${ }^{34}$.

The JŽDD conveyed a Yugoslav identity that was encapsulated in a concept of integral Yugoslavism, probably close to that of the dominant Democratic Party in Sušak ${ }^{35}$ even if it initially adhered to a campaign in favour of women's suffrage. ${ }^{36}$ At the time of its foundation, it made a particularly inclusive plea, addressing every "conscious Yugoslav woman, whether she is a factory worker, a domestic worker or a clerk, the wife of a rich man, an artisan or a merchant". ${ }^{37}$ It nurtured the ambitious goal of organising classes for illiterates, opening reading rooms and libraries, but also caring for abandoned youth in Fiume, Sušak and in the surroundings.

In the local context, where the margins of the Croatian language - considered inferior to Italian - had been further narrowed during the D'Annunzian period, culture came to represent an emancipatory tool both for the Yugoslav population and for its female component. The fact that education played an essential role in the creation of the new state and that educated women had the moral duty to put themselves at the service of the cause was also the main thesis conveyed in the editorial that opened the first issue of the magazine "Jugoslavenska žena" [The Yugoslav woman]. This is how the originally Slovenian feminist - and also a staunch Yugoslavist - Zovka Kveder addressed the magazine's female readers:

[S]isters, any among you who can read and write, wherever you are, put your strength at the service of the just liberated Yugoslavia. May each of you be a teacher for your sisters, a preacher in your social circle, may you enhance the idealism of your husband, brother, son, parents and acquaintances. ${ }^{38}$

Published in Zagreb, the magazine recounted the events of Fiume and Sušak, ${ }^{39}$ passed on the greetings of a woman from Baška (on the isle of Krk), on the verge of launching a local library, reported the JŽDD's first-ever meeting in Sušak ${ }^{40}$ whereas other letters - often written by women teachers - testified to a widespread activism that also involved smaller cities.

The unifying message also became evident from the fact that the association comprised both Croatian women - which also made up the initial majority of members - and Serbian women, like its president, Milica Vidović. Although

${ }^{34} 1309$ in Hrvatski državni arhiv (HDA), Zbirka pravila, F 1353 Grupa VI.

${ }^{35}$ Ž. Bartulović, Sušak, pp. 94-101.

${ }^{36}$ Skupština žena u Zagrebu za pravo glasa, "Jugoslavenska žena” (hereafter JŽ), 1919, pp. 118-119.

${ }^{37}$ Vesnik, "PN", 30 January 1919, p. 3.

${ }^{38}$ Zofka Kveder, U kolo, "JŽ", 1919, p. 1.

${ }^{39}$ Sa Sušaka mi piše učiteljica, "JŽ”, 1919, pp. 47-48.

${ }^{40}$ Vijesti sa Sušaka i Baške, "JŽ”, 1919, pp. 126-127. 
she came from an area with a very small Serbian minority, at the Congress of Yugoslav women in Belgrade Vidović represented the women of the coastal area that the Italians had occupied. ${ }^{41}$

The ambiguity between the Yugoslav and Great-Serbian ideals was reflected in the political capital of Serbian women within the pro-Yugoslav associations, also in view of the war effort they had given proof of on the winners' front. ${ }^{42}$ Vidović, who had already directed earlier philanthropic initiatives both in a local context and aimed at the Serbian population, ${ }^{43}$ continued to strengthen the link between Sušak and Belgrade, for example by collecting funds for the Society for the protection of the Yugoslav children, which assisted orphans of fallen war heroes. ${ }^{44}$ She also hosted the Serbian feminist Delfa Ivanić, who visited Sušak in 1919, during one of her trips ${ }^{45}$ The lectures they organized covered a variety of topics: women's emancipation, ${ }^{46}$ Yugoslav-inspired politics, ${ }^{47}$ topics that conveyed a profoundly traditionalist image, as emerges from the lesson Vidović herself gave, which drew on Serbian epic poetry in the recollection of the role played by Mother Jugović, whose nine sons are said to have died heroically in the battle of Kosovo Polje. ${ }^{48}$ Similar contradictions could also be discerned in the activities carried forward by Zovka Kveder, who had inspired the JŽDD. Although prior to the conflict she had demonstrated a socialist and pacifist orientation, in the framework of the young state she increasingly championed women's inclusion in a platform of integral nationalism. ${ }^{49}$ Exemplary of this change might be the work Arditi na otoku Krku [Storm troops on the isle of Krk]; it presented female roles that were strongly rooted in traditional gender standards while embracing a narrative of war heroism. ${ }^{50}$

The enthusiasm with which the Yugoslav idea had been welcomed soon weakened, especially in Croatia, due both to the feeling that the Serbian element became dominant and that the state itself was dysfunctional. ${ }^{51}$

${ }^{41}$ Adela Milčinović, Kongres jugoslavenskih žena u Beogradu, "JŽ”, 1919, pp. 281-286.

${ }^{42}$ Ida Ograjšek Gorenjak, Opazne iluzije: rodni stereotipi u međuratnoj Jugoslaviji, Zagreb, Srednja Europa, 2014, pp. 73-74.

${ }^{43}$ Vesnik, "PN", 8 April 1919, p. 3.

${ }^{44}$ Vesnik, "PN", 23 July 1919, 3 August 1919, p. 3.

${ }^{45}$ Vesnik, "PN", 6 June 1919, p. 3. Jasmina Milanović, Delfa Ivanić. Zaboravljene uspomene, Belgrade, Evoluta, 2015, pp. 207-208. I am grateful to Isidora Grubački for pointing me to this.

${ }^{46}$ Vesnik, "PN", 25 February 1919, p. 3

${ }^{47}$ Vesnik, "PN", 5 April 1919, 27 April 1919, p. 3.

${ }^{48}$ Vesnik, "PN", 11 February 1919, p. 3.

${ }^{49}$ Andrea Feldman, Poričući gladnu godinu: Žene i ideologija jugoslavenstva (1918.-1939.), in Jelka Vince Pallula et al., Žene u Hrvatskoj, Zagreb, Institut "Vlado Gotovac" - Ženska infoteka, 2004, pp. 239-240.

${ }^{50}$ Natka Badurina, Od strepnje do autoritarnog subjekta (ideološki zaokret Zofke Kveder), in Riječki filološki dani, Rijeka, Filozofski fakultet, 2010, pp. 17-36.

${ }_{51}$ Dejan Djokić, Elusive compromise: a history of interwar Yugoslavia, New York and London, Columbia University Press, 2007; Pieter Troch, Yugoslavism between the world wars: indecisive nation building, "Nationality paper", 2010, n. 2, pp. 227-244. 
Additionally, many women became disaffected with politics after the postconflict window of opportunity for a democratic climate that was favourable to universal suffrage was closed. ${ }^{52}$ In the early $1920 \mathrm{~s}$, when different legal systems coexisted in the Kingdom of SCS, women in Croatia and Slavonia enjoyed an extremely limited voting right - conditioned by their patrimonial and professional status, or by their educational level - and only in local elections, which they probably lost in $1923 .{ }^{53}$ Given that local elections in Sušak were repeatedly postponed in light of the Italian occupation, some women managed to vote only once, in $1923 .{ }^{54}$ Furthermore, only one list presented itself in these elections, confirming the status quo. ${ }^{55}$

However, the hopes for a more intense participation had been shattered previously, as a situation recorded by the Information Office of D'Annunzio's government illustrates. In January 1920, during a meeting of Sušak's Electoral Committee, the proposal for a new electoral law was submitted for an advisory vote; it included, among its various points, the extension of the voting right to women. The majority of voters expressed their disapproval, after which "some [women] teachers and women [...] protested against the dissenting vote". ${ }^{56}$ Moreover, concrete difficulties were encountered in the attempt to mobilise women, as demonstrated by the fact that - notwithstanding the many appeals - only one woman signed up for the course for illiterates in Sušak. ${ }^{57}$ As post-war enthusiasm waned, the opposite tendency to draw women back into the domestic sphere increasingly seemed to take shape. ${ }^{58}$ If in pro-Yugoslav women's associationism two souls coexisted, one being more sensitive to the expansion of political rights, the other more conservative, linked to the ruling dynasty of Yugoslavia and relegating women's participation to the philanthropic sphere, ${ }^{59}$ the latter seems to have taken over in subsequent years.

\section{Women, political passion and violence}

The aforementioned article-manifest that Pedrazzi published in "La Vedetta d'Italia" also made reference to one of the most obscure events that marked the

${ }^{52}$ Irena Selišnik, Female suffrage in Slovenia, in Blanca Rodríguez-Ruiz, Ruth Rubio-Marín, (eds.), The Struggle for female suffrage in Europe: voting to become citizens, Leiden-Boston, Brill, 2012, p. 340; I. Ograjšek Gorenjak, Opazne iluzije, pp. 89-90.

${ }^{53}$ I. Ograjšek Gorenjak, Opazne iluzije, pp. 95, 101-102.

${ }^{54}$ Ž. Bartulović, Sušak, p. 98.

${ }_{55}^{5}$ Poslije gradskih izbora, "Primorski Novi List" (hereafter "PNL"), 5 June 1923, p. 1.

${ }^{56}$ Italian Army Command in Fiume of Italy Information Office, 27 January 1920, in Državni arhiv u Rijeci (DARI), Privremene vlade, kk. 18-19.

${ }^{57}$ Vesnik, "PN", 5 August 1919, p. 3.

${ }^{58}$ I. Ograjšek Gorenjak, Opazne iluzije, p. 113.

${ }^{59}$ Isidora Grubački, The emergence of the Yugoslav interwar liberal feminist movement and The Little Entente of Women: an entangled history approach (1919-1924), "Feminist encounters", 2020, n. 2. 
post-war period in Fiume. ${ }^{60}$ In July 1919, a crowd composed of paramilitaries and civilians assaulted and lynched a group of French colonial soldiers, killing nine. This burst of violence was followed by the creation of an Inter-allied Commission, which was to determine the responsibilities of Fiume's Battalion, the paramilitary formation founded by Giovanni Host Venturi, who would eventually come to represent the most unyielding branch of Fascism in Fiume. ${ }^{61}$

It is likely that the local press played a not insignificant role in fomenting a climate of hatred against the colonial troops from French Indochina, often remembered as "Annamite" or "Vietnamese". In doing so, it partially drew on gender stereotypes. A week prior to the attack, "Il Giornale" had published an article where the French contingent was described as "those yellow little monsters that roam around our city" and as "primitive and obscene beings", accused of having undressed on the beach and harassed Fiumian women. ${ }^{62}$ Moreover, many later sources mention an incident in which a drunk, French soldier allegedly ripped a cockade with the colours of the Italian flag from a Fiumian woman's chest, ${ }^{63}$ damaging her honour and, accordingly, that of Italy. Although it is impossible to reconstruct the facts, the account of this incident seems relevant as it testifies to the coexistence of contrasting trends in the Italian nationalist milieu that D'Annunzio theatrically barged into on 12 September 1919. On one side, the article introduced the metaphorical representation of the foreigner who threatens the woman's integrity, a recurrent topos in nationalist narratives of the nineteenth century, ${ }^{64}$ which was reinforced by the presence of colonial troops. ${ }^{65}$ On the other side, women continued to be described - in particular during the first months of D'Annunzio's rule, but also further ahead - as patriots equally willing not just to sacrifice themselves for the nation and to grieve their loved ones, but also to take the initiative on the field, up to the point of becoming the very protagonists of violent acts. In this intense local climate, with the possibility of demobilisation still far ahead, the pro-Italian sector initially welcomed women into the violent sphere, which seemed inseparable from the political battle. The apparent paradox of extending suffrage, supported by nationalist and militarist political actors, as well as their closeness to the women's associations, was not a distinct feature of Fiume but could also be spotted in adjacent areas. The Italian feminist associa-

${ }^{60} \mathrm{O}$. Pedrazzi, Le donne fiumane.

${ }^{61}$ W. Klinger, Un'altra Italia, p. 310.

62 Oscenità spudorata, "Il Giornale", 1 July 1919, p. 2.

${ }^{63}$ Edoardo Susmel, La città di passione. Fiume negli anni 1914-1920, Milan, Treves, 1921, p. 212; Gino Berri, La gesta di Fiume. Storia di una passione inesausta, Florence, R. Bemporad, 1920, p. 12; Giovanni Host-Venturi, L'impresa fiumana, Rome, G. Volpe, 1976, p. 75.

${ }^{64}$ Alberto Mario Banti, L'onore della nazione: identità sessuali e violenza nel nazionalismo europeo dal 18. secolo alla grande guerra, Turin, Einaudi, 2005, p. 260.

${ }^{65}$ Anne McClintock, Imperial leather: race, gender and sexuality in the colonial contest, New York-London, Routledge, 1995. 
tions, of which an important part had embraced interventionist and nationalist positions during and after the conflict, continued to fight for suffrage, which seemed at hand in the first months following the conflict. ${ }^{66}$

Women's suffrage, introduced by the CNI's decision of August 1919, shortly before D'Annunzio's arrival in Fiume, became a reality in the October elections; ${ }^{67}$ not only many women voted in these elections, but three women were even elected into the citizen's council. ${ }^{68}$ D'Annunzio's direct appeal to the crowds required unconditional support - even devotion - to his figure. All these elements emerge from the descriptions of the popolane: the women of the Old City, who were represented as irrational actors, tending towards fanaticism and ready to blindly obey a leader's orders, though also capable of giving solemnity to political rituals. "La Vedetta d'Italia" thus reported the Fiumian women's euphoria as they voted for the first time, showing images of elderly and disabled women being carried on stretchers into the polling station. This enthusiasm also infected women without pertinenza ${ }^{69}$ that is, women who could not vote; a certain Carmela Pagan, for example, allegedly declared that she was willing to throw herself into a fire for the Italian flag. In the press, women voters gave different reasons for voting the National Union list: from an unconditional love for either Italy or D'Annunzio to the possibility to keep control over the harbour and rail system in case of annexation. There were also motivations that implicitly seemed to diminish the vote's political function, as certain young ladies said they wanted to avoid seeing the Italian soldiers leave. ${ }^{70}$

The devotion of the Fiumian popolane for D'Annunzio also seems to emerge from other sources. According to a report by the Information Office, the women of the Old City had allegedly made a sign of the cross at D'Annunzio's passage, requested that he baptised a newborn and voted against the approval of a plebiscite. Indeed, in December 1919, the Fiumian population was called to decide whether to accept a compromise from the Italian government or to sustain the immovable line represented by D'Annunzio. ${ }^{71}$ Although the citizens voted in favour of the former option, the vote was subsequently nullified by D'Annunzio's government.

The mysticism of patriotism and war was glorified by the incident of the dagger's benediction, when Fiumian women symbolically donated the weapon

${ }^{66}$ Emma Schiavon, The women's suffrage campaign in Italy in 1919 and Voce nuova ("New voice"): corporatism, nationalism and the struggle for political rights, in I. Sharp, M. Stibbe (eds.), Aftermaths of War, p. 52.

${ }^{67}$ Verso le elezioni della Civica rappresentanza, "Il Giornale", 25 August 1919, p. 2.

${ }^{68}$ L'esito delle elezioni, "VI", 28 October 1919, p. 2.

${ }^{69}$ Pertinenza was a bureaucratic category that had originated in the Austro-Hungarian Empire, linking political rights to the place of origin.

${ }^{70}$ Il trionfo di Domenica. Episodi della giornata elettorale, "VI", 29 October 1919, p. 2.

${ }^{71}$ Italian Army Command in Fiume of Italy Information Office, 19 and 26 December 1919, in DARI, Privremene vlade, kk. 18-19. 
to D'Annunzio. Contemporary testimonies focused on the juxtaposition between violence and religion. Thus, the dagger was considered "sacred", and it was said that the the Fiumian women "religiously donated" it in the hope that it might be used to engrave the word "Victory" in the enemies' living flesh; the hilt allegedly carried the writings "Italy or death" on one side, "Fiume or death" on the other. ${ }^{72}$ The theme of the parallel between Christ's and the soldier's sacrifice was rooted in the First World War as well as in the actions of certain Catholic exponents. The latter saw the conflict as an opportunity to impose a new central role of the Church onto the national-patriotic discourse, like Father Giuliani who celebrated the ceremony - a priest who had acted as a military chaplain during the war and who had distinguished himself for his fascist activism, eventually dying during the colonial war in Ethiopia. ${ }^{73}$ Moreover, post-war radicalism often drew on religious language in an attempt to oppose sentiment to rationality. ${ }^{74}$

The exploitation of Christian topoi continued with the comparison between the martyrdom of Saint Sebastian - whose name day fell on the day of the donation of the dagger, and to whom the church that hosted the ceremony was dedicated - and that of D'Annunzio, who was ready to give his life for Fiume. ${ }^{75}$ The figure of the popolana, for what it represented, seemed useful only to offer irrational political support to the leader. However, the pages of "La Vedetta d'Italia" also describe female figures of the Old City passing concrete requests on to D'Annunzio, seeking to exploit their support for the cause. As early as the first half of October 1919, a number of popolane wanted to send a delegation to the Commander to denounce what was considered incorrect behaviour by certain merchants. ${ }^{76}$ Nevertheless, the fact that the citizens' call for participation was not taken too seriously soon became clear; when 400 women - including higher-class women and popolane - were summoned before the municipality, the authorities refused to receive them. ${ }^{77}$

Despite the proclamations made in favour of women, and their presence in local political rituals, women's participation mostly turned out to be of a

${ }^{72}$ Le donne fiumane al comandante D'Annunzio, "VI", 17 January 1920, p. 2; Il devoto omaggio delle donne fiumane a D’Annunzio, "VI", 21 January 1920, p. 2; Ferdinando Gerra, L'impresa di Fiume, Milan, Longanesi, 1974-1975, p. 268.

${ }_{73}$ Alberto Mario Banti, Sublime madre nostra. La nazione italiana dal Risorgimento al fascismo, Bari-Rome, Laterza, 2011, pp. 119-137. For a general analysis of the sacralisation of the conflict see George L. Mosse, Le guerre mondiali: dalla tragedia al mito dei caduti, Rome-Bari, Laterza, 2018.

${ }^{74}$ Emilio Gentile, Il mito dello Stato nuovo dall'antigiolittismo al fascismo, Rome-Bari, Laterza, 1999, p. 16.

${ }^{75}$ Marko Medved, Riječka crkva u razdoblju fašizma. Nastanak biskupije i prvi talijanski upravitelji, Zagreb, Kršćanska sadašnjost, 2015, pp. 170-172.

${ }^{76}$ Italian Army Command in Fiume of Italy Information Office, 10 November 1919, in DARI, Privremene vlade, kk. 18-19.

${ }^{77}$ Una chiamata inutile, "VI", 1 November 1919, p. 2. 
formal kind. Many photographs immortalised the numerous female activists that flocked to the Adriatic city to offer their support to the front that wished to be annexed to Italy. Some of these, while not playing any real political role, transformed themselves into the symbols of militaristic iconography, like the Marchioness Margherita Incisa da Camerana, portrayed in the uniform of an ardito (storm trooper), ${ }^{78}$ or Lina Igliori, who posed with a Roman dagger hanging from her waist. Far more relevant was the presence of women of the likes of Tullia Franzi, who founded a school for legionnaires ${ }^{79}$ or Teresita Pasini (alias Alma Dolens), who was engaged in care work activities; similar women gave continuity to that juxtaposition between nationalism, irredentism and humanitarianism that was born during the First World War, in which women had played an important part. Yet, on the pages of the pro-annexation press it is impossible not to note their limited presence, in spite of the huge effort they made.

Likewise, the presence of Fiumian women activists who had been involved in irredentist associationism was also rather scant, except in the early months following the end of the conflict. These women do not seem to have taken any specific stance on women's participation; on the contrary, in some cases they even embraced a conservative view on women's role and gender relations. For instance, the aforementioned Emma Brentani — who had become head of a city school after the war - expressed her disapproval of granting women access to technical courses, in that they "contribute to damage society by depriving it of women who understand their true and noble passion", hoping that "the majority of working-class daughters refrain from taking - and rightfully so, if they are not to create an excessive number of misfits - the path of higher institutes". ${ }^{80}$

The staunch support of many Italian feminists for the Endeavour of Fiume does not seem to have led to any direct contacts or mutual influences. ${ }^{81}$ Local political events were monitored on the pages of the "Voce nuova", which represented this sector, through the writings of the Trieste-based journalist Ada Sestan, who manifested a particular interest in the elections and in the women's vote. ${ }^{82}$ "La Vedetta d'Italia", by contrast, overflowed with images depicting

${ }^{78}$ Incisa da Camerana, who during the first post-war period took the surname of her husband Rossi Passavanti, had already visited Fiume at the eve of D'Annunzio's expedition and established contacts with Host Venturi in order to volunteer as a nurse. Margherita Rossi-Passavanti d'Incisa, Nella tormenta MCMXV-MCMXIX, Rome, Colombo, 1929, p. 250.

${ }^{79}$ Giuliana Bertacchi, Da Alzano a Fiume: Tullia Franzi attraverso le carte del suo archivio. Mostra documentaria: Alzano Lombardo, Biblioteca comunale, 17 novembre - 30 novembre 2001, Vilminore di Scalve, Il filo di Arianna, 2001.

${ }^{80}$ Verbal proceedings of the second conference held on 7 October 1919 by the Teaching corps of the Italian female city school in DARI, Školsko vijeće, k. 52.

${ }^{81}$ E. Schiavon, The women's suffrage campaign.

${ }^{82}$ See, for example, Ada Sestan, Le elezioni a Fiume, "Voce nuova", 11 November 1919, p. 2. 
women as they "give their assistance" to male figures, not just in a private context but also in a public one; the daily thus recalled the assistance women had given to the Italian prisoners during the war, or the cult of the dead, with recurrent images of mothers commemorating their deceased sons. ${ }^{83}$

In some cases the contradiction was evident, as with the public figure of the Ligurian Maria Vitali. After settling permanently in Fiume, she founded the association of the Guardians of the Dead, with the purpose of looking after the fallen soldiers' tombs. On one side, Vitali embraced the eternal auxiliary role that has been attributed to woman, even presenting herself as "the betrothed of the dead"; 84 on the other side, she strongly claimed her presence in the public sphere and promoted what would have been the only women's association in post-war Fiume of significance. She accused "La Vedetta d'Italia" of not granting her the desired space, and entrusted her publications to the fascist journal "Il Popolo di Fiume". ${ }^{85}$

During 1920, there was an increase of repressive measures of D'Annunzio's rule, as well as of political violence and common criminality, the last perpetrated by various actors who had poured into the city. D'Annunzio's expulsion from Fiume by the Italian government, in December 1920, did not bring an end to the tensions. It was in this climate of instability that the city prepared for the Constituent Assembly elections of April 1921, with an annexationist and an autonomist list vying for votes; thus, in the first real electoral competition that took place in Fiume, women's support could have been decisive. Although in previous months women's presence in the local press had increasingly thinned out, on the eve of the vote both formations appealed to women's suffrage. In a rhetoric context where all parties tended to address voters of both sexes - that is, using both masculine and feminine word forms - not even the local Fascio was an exception to this, addressing the crowd at an assembly with "tutti $i$ fascisti e le fasciste" [all fascists, male and female"]. ${ }^{86}$

Claiming that Fiumian women would have been the first Italian women to express their political will, "La Vedetta d'Italia" accused the autonomists of wanting to deprive them of their right to vote. ${ }^{87}$ In reality, the autonomist party equally addressed women voters, with its numerous female activists coming from both the middle and the working classes, especially from the tobacco

${ }^{83}$ Robin Pickering-Iazzi (ed.), Mothers of invention. Women, Italian fascism and culture, Minneapolis-London, University of Minnesota Press, 1995, p. X.

${ }^{84}$ Misc. 7, 28, fasc. Le Custodi dei morti in Società di studi fiumani - Archivio Museo Storico di Fiume; Maria Vitali, Modello novantuno: memoria di una cittadina senza importanza, Rome, s.n., 1974.

${ }^{85}$ Ostruzionismo, "Il popolo di Fiume. Settimanale di battaglia" (hereafter "PF"), 9 November 1921, p. 2; La riconciliazione dei morti, "PF", 11 March 1922 and 13 March 1922, p. 1.

${ }^{86}$ Adunata fascista, "VI", 2 February 1921, p. 2.

${ }^{87}$ Alle donne di Fiume, "VI", 21 April 1921, p. 1; L'incitamento di Orazio Pedrazzi, "VI", 24 April 1921, p. 2 
industry. The autonomist paper "Fiume dei fiumani" appealed precisely to the latter, inviting them to vote the Torre Civica list so as to "become women again and no longer slaves as you are now" ${ }^{88}$ If suffrage clearly brought empowerment along with it, old prejudices resurfaced in the new context: while they tried to gain their consensus, both competitors considered women voters weak links, more easily purchasable than men. ${ }^{89}$

\section{Gender stereotypes and prejudices of political and national nature}

The theme of political participation represented only a minor part of women's exposure in the media. Other useful sources to reconstruct gender representations in the local collective imagination consist in the images that can be drawn from the press, mainly from crime news and local columns.

If subsequent accounts have tended to attribute the myth of a revolutionary enthusiasm capable of breaking sexual norms to the case of Fiume, a more complex situation emerges if we look at the press of the time. Many newspaper articles highlight the presence of a significant liberty from family restrictions among Fiumian women, a relative tolerance of premarital relations and a very strong female presence on the job market, from working-class to white-collar jobs. All these elements were typical of a secular and cosmopolitan harbour city with a Central-European tradition,,$^{90}$ but would have struck contemporary observers as unusual. ${ }^{91}$ Furthermore, accounts of promiscuity should probably need to be related to the strong presence of prostitutes in the city, which were often very young girls who lived in conditions of profound misery. ${ }^{92}$

The Fiumian futurists' newspaper, "The Iron Head", purposely promoted a sexual metaphor of D'Annunzio's expedition, stressing the idea of possession. The newspaper, which proclaimed the cult of masculinity ${ }^{93}$ hosted a column titled Woman... by Margherita Besozzi Keller, alias Fiammetta. A noblewoman from Milan, Besozzi Keller was the wife of a Fiumian legionnaire, and the cousin of Guido Keller, one of D'Annunzio's closest collaborators; Besozzi Keller herself would enter into a relationship with D'Annunzio. ${ }^{94}$ In

${ }^{88}$ Cose della Fabbrica Tabacchi, "Fiume dei fiumani! Giornale di battaglia. Contro gli usurpatori, gli oppressori e gli sfruttatori di Fiume", 23 April 1921, p. 1.

${ }^{89}$ Tra uno sciopero e l'altro, "VI", 22 February 1921, p. 2.

${ }^{90}$ Ilona Fried, Fiume città della memoria, 1868-1945, Udine, Del Bianco, 2005, pp. 10, 33-35.

${ }^{91}$ Paolo Santarcangeli, Il porto dell'aquila decapitata, Udine, Del Bianco, 1988, pp. 150-151.

${ }^{92}$ Quelle signore, "VI", 4 October 1919, p. 2.

${ }_{93}$ Gabriele D'Annunzio, La maschiezza resta a Fiume, "La Testa di ferro" (hereafter TF), 15 August 1920, p. 1.

${ }_{94}$ Gabriele D'Annunzio, Lettere a Fiammadoro, edited by Vito Salierno, Rome, Salerno, 2001. 
her column, Fiammetta boasted that she was the lover of an ardito, that she smoked and indulged in luxuries that she could afford thanks to her journalistic work, and that she had enjoyed many love affairs..$^{95}$ At the same time, she encouraged women to free themselves from moral constraints, and cast the Fiumian women off as negative examples in the experimental magazine "Yoga", accusing them of conservatism:

notwithstanding the divine light that radiates today from the City of life and love, the Fiumian woman is perhaps the only among all Italian women to be, and who rejoices in being, a moralist. A moralist in the full vile sense of the word. ${ }^{96}$

Since "The Iron Head" would soon collide with D'Annunzio's entourage, continuing its publications from Milan, Besozzi Keller would also leave the Adriatic city. Rather than a plea for women's emancipation, her words seem to reflect a separation between the imagined and the real city. Indeed, if a group of followers initially welcomed D'Annunzio, who had been invited by the city authorities themselves, a silent divide between D'Annunzio's entourage and the local citizenry had increasingly widened. This was due also to the isolation the Italian government had imposed upon the city, its catastrophic economic conditions and the authoritarian behaviour of the legionnaires and arditi that had flocked to Fiume at different stages.

The sexualisation of the conflict was also prominent in the opposition press, which transmitted an image of Fiume as the reign of vice and moral corruption. Here, too, the city's feminisation served as a metaphor for the occupation viewed in terms of a sexual conquest or as an act of sexual violence, also widely exploited in the Croatian/Yugoslav context. ${ }^{97}$

Such a representation of the city was not mere rhetorical device; it was corroborated by various chronicles. Sušak newspapers thus recounted the stories of Fiumian women - often pregnant - who had been abandoned by Italian soldiers. Some cases caused an uproar, like that of an Italian lieutenant who had failed to show up at his "reparatory marriage" to a Fiumian woman. According to D'Annunzio's entourage, "Primorske novine" exploited this incident "to discredit the Italians by accusing them of lies and perjury". In the end, the wedding took place following pressure from the lieutenant's superiors, although he eventually vanished. ${ }^{98}$ The act of getting involved with Italian

${ }^{95}$ Fiammetta, Donna... Mi presento, "TF", 29 August 1920, p. 2.

${ }^{96}$ Fiammetta, Donne!!!, "Primo quaderno della Yoga-Il ballo di San Vito", June 1920; C. Salaris, Alla festa della rivoluzione, p. 60.

${ }^{97}$ Ana-Maria Milčić, Od karata na papiru do ženskoga tijela: Futuristi i satiričari u D’Annunzijevoj Rijeci, in Tea Perinčić Mayhew, D'Annunzijeva mučenica-L'Olocausta di D'Annunzio-D’Annunzio's Martyr, Rijeka, Povijesni i pomorski muzej Hrvatskog primorja, 2019, pp. 3553.

${ }_{98}$ Italian Army Command in Fiume of Italy Information Office, 30 June 1920, in DARI, Privremene vlade, kk. 18-19. 
soldiers was stigmatised, occasionally also by the Church, as in the nearby village of Cernik, where the vicar warned girls to stay away from the Italian soldiers. ${ }^{99}$

The Croatian-language press in Sušak adopted the Italian word giovanotti (youngsters) to mockingly mark the exasperated masculinity of the violent characters that engaged in the disturbances; these were described as destructive elements and "barbarians", keen on showing their patriotism through terror, sarcastically responding to the Italian nationalist call for Latin "civilisation". 100 From the earliest days of D'Annunzio's march into the city, rumours spread about the Italian soldiers committing acts of sexual violence. Thus, Zagrebačke novine mentioned the abduction of 22 girls, aged between 12 and 15 years, two of whom were allegedly raped, although no traces of this incident can be found. ${ }^{101}$

The metaphor of D'Annunzio's occupation as a rape also emerges from the autonomist press, especially from 1921 onwards. After D'Annunzio was chased out by the Italian army, the hundreds of legionnaires that had remained in the city - along with many local fascists or foreigners - provoked a climate of continued violence, perpetrated through fascist action squads at the expense of opponents, while also engaging in acts of common criminality and oppression. As early as 1920, a document written by the autonomists accused D'Annunzio of having provoked a "moral and economic dissolution", of having transformed Fiume "into a brothel" and of not "respecting women's honour", ${ }^{102}$ even of having sexually abused minors. An article published in the autonomist newspaper "La Voce del popolo", two years later, added insult to injury when it attacked "the liberators of Fiume" because they had allegedly "contaminated and infected far too many girls between 12 and 16 years of age", "vilified the name of the Fiumian women, treating them as if they were their lovers and friends, as if they were their prostitutes", and perpetrated every imaginable form of violence. ${ }^{103}$

Furthermore, we must consider the fact that the pro-Yugoslav press of Sušak had long transmitted an image of Fiume both as a centre of modernity and as a threat to traditions. If for Sušak's inhabitants the larger city of Fiume remained - well into the 1920 s — a reference point for various social prac-

${ }^{99}$ Italian Regency of Carnaro. Italy Information Office, 4 November 1920 in DARI, Privremene vlade, kk. 18-19.

${ }^{100}$ Riječki izbori.

${ }^{101}$ Italian Army Command Information Office, 6 February 1920, p. 3, DARI, Privremene vlade, kk. 16-17.

${ }^{102}$ See the proclamation Cittadini e cittadine! of March 1920, in Società di studi fiumani Archivio Museo Storico di Fiume, fondo Zanella.

103 Per non dimenticare. I meriti dei nostri liberatori, "La Voce del popolo" (hereafter “VP"), 9 September 1922, p. 2. 
tices, from shopping to cinema and theatre-going but also brothels ${ }^{104}$ the city was described as a place of widespread cocaine consumption, where the café chantant were extremely popular and extramarital relations were common, and where numerous love-related suicides affected youth. ${ }^{105}$ Especially the pages of "Sušački Novi List", Sušak's main newspaper from 1925 onwards, probably also driven by the misogynist tendencies of its founder Nikola Polić, pointed the finger against modernity's negative influence on women's physical appearance (bob, dyed hair, face powder), ${ }^{106}$ musical taste (foxtrot) and moral characterisation (the image of the "demon woman"). ${ }^{107}$

Both the pro-Yugoslav and the autonomist press reversed the narrative promoted by the pro-Italian parties, namely that which presented the legionnaires as the "the liberators of Fiume" and as the representatives of a superior civilisation. The newspapers that contrasted Italy's annexation politics instead described the legionnaires as "occupiers" living at the expense of the Fiumian population: ${ }^{108}$ an alien presence in local society. A negative stereotype that frequently emerged was that of the regnicoli, citizens of the Kingdom of Italy until 1918, coming from areas that were considered historically and culturally distant from Fiume. Just like the Italian nationalist press tended to promote an anti-Slav stereotype, which cast the Slovenes and Croates as populations of inferior cultural development, strongly rooted in a rural and almost savage world, ${ }^{109}$ the opposing sectors replied with a - to a degree - comparable image of the legionnaires and fascists that had flocked to the city; these were described as being native to southern Italy, violent, uneducated sexual predators. While the opposition press is full of such stereotypes, ${ }^{110}$ its most exemplary representation can be found in a letter addressed to an editorial board (presumably that of "La Vedetta d'Italia"), but never published. The document evokes the image of a city at the mercy of so-called "liberators", who would have transformed themselves into "masters", reducing the Fiumian inhabitants to mere "guests". The newly arrived - many of whom are described as "tiny southerners" who had allegedly imported the Mafia into the Kvarner region - are said to have corrupted minors and seduced young women, driving

104 Odnošaji izmedju Sušaka i Rijeke, "Sušački Novi List” (hereafter "SNL”), 19 April 1925, p. 2.

${ }^{105}$ Mjesne i društvene vijesti, "SNL", 8 August 1925, p. 3.

${ }^{106}$ Policija i bubikopf, "SNL", 6 October 1925, p. 3.

${ }^{107}$ Mjesne i društvene vijesti, "SNL", 7 and 8 August 1925, p. 3; http://fluminensia.org/tag/ nikola-polic.

${ }^{108}$ Per non dimenticare; Jǒ̌ jedan dokumenat kulture i civilizacije, "SNL", 26 June 1923, p. 3.

${ }^{109}$ For a historical overview of the creation of this stereotype see Tullia Catalan and Erica Mezzoli (eds.), Antislavismo. Discorsi e pratiche in Italia e nell'Europa sudorientale tra Otto e Novecento, special issue of "Memoria e ricerca", 2018, n. 3.

${ }^{110}$ See, for example, Il diritto di cittadinanza, "VP", 23 April 1922, p. 5; Mjesne i društvene vijesti, "PNL", 3 October 1923, p. 3; Jedan grozan zločin, "SNL”, 27 March 1925, p. 3. 
them to suicide or prostitution, and committed numerous atrocious crimes at the expense of women. ${ }^{111}$ The fact that the letter was probably written by an observer close to the local Fascio demonstrates that the tensions between the newly arrived and the Fiumian citizens went beyond political factions. An exotic representation of southern Italy, described as a place of violence and organised crime, was thus opposed to an even more exotic account of the Balkan world, within a collective imagination where the relations of proximity that had originated in the context of the Habsburg Empire still seemed very relevant, despite attempts to construct new national allegiances.

The anti-Slav stereotypes that thrived during D'Annunzio's rule, ${ }^{112}$ and which culminated in the fascist period, ${ }^{113}$ were equally conditioned by gender representations. In this regard, it is worth mentioning an article published in "La Vedetta d'Italia" in 1922; it mocked a Croatian girl named Mimiza, a mlekarica who had attempted to adapt to the urban context. The mlekarice were women who carried milk from the neighbouring municipalities to the city, sometimes walking more than ten kilometres per day. ${ }^{114}$ These women represented not only a link between the city and its hinterland, but they also symbolised the idea of a rurality linked to the Croatian world, which in reality was no less stratified than the Italian one. Thus, if the countryside was densely inhabited by Croatianspeaking people, the cities of Fiume and Sušak hosted both a merchant population and a working class that spoke Croatian and also — to a smaller extent - Slovenian. Yet, the above-mentioned article offered a demeaning image of Mimiza's Croatianness, which associated women with a "stinking wet dog smell" whereas the "Slavs" supposedly danced an unspecified "bear dance", which would certainly have appeared ridiculous to the sophisticated guests. ${ }^{115}$

\section{Conclusion}

My analysis of women's presence in public space and gender stereotypes in the local press of the neighbouring municipalities of Fiume and Sušak sheds light on a number of similarities and differences.

${ }^{111}$ Letter to the editors, n.d., in DARI, Privremene vlade, kk. 18-19.

112 Suffice to think of the rants against "the filthy Serbian swineherd" (Spalato of 13 July 1919, in Gabriele D'Annunzio, La penultima ventura: scritti e discorsi fiumani, Milan, Mondadori, 1974, p. 276), aimed at stirring up tensions in July 1920 when, following a mysterious incident in Spalato, fire was set to the Narodni dom in Trieste and shops owned by Yugoslav merchants in Fiume were attacked.

${ }^{113}$ In the days running up to 2 June 1928, the opening article entitled 'Inferior animals' was published in the newspaper "La Vedetta d'Italia". It raised polemics across the border, leading the Italian prime minister to request that the director of the Fiumian newspaper be removed from his job. See fasc. La Vedetta d'Italia in DARI, Riječka prefektura, k. 1.

${ }^{114}$ Report on crafts, trades and industries and any economic activity in the area of the Sušak district for the months May and June 1930, in HDA, Politička zbirka, 1883.

${ }^{115}$ Aristocratici in frack e dame in decolté, "VI", 18 January 1922, 2. 
In both cases, in the first post-war period women claimed a presence in public space which also included the political sphere. In fact, in many cases women became the protagonists of demonstrations in support of the nascent political-national, pro-Italian and pro-Yugoslav projects, but also in favour of Fiume's autonomy. While these were not the only political options at stake, they were undoubtedly the most visible ones, not to mention those that could count on a more structured organisation.

Within Italian nationalism in Fiume, politics gained an unprecedented, mass dimension that was enforced by D'Annunzio's expedition, and which implied a will to include women in the public sphere. Nonetheless, this responded to the need to guarantee support for the dominant cause and deprived women of a political subjectivity of their own. Paradoxically, the concession of universal suffrage and women's inclusion in the nationalist discourse neutralised one of the principle battles of contemporary women's associationism from within, preventing women from acting independently. Not even the pro-annexation activism of many exponents of the Italian middle and lower middle class managed to produce any connections with women from Fiume's civil society, whereas philanthropic women and external agitators struggled to establish relations on a local level.

The autonomist group, which developed in the course of 1919 in opposition to the D'Annunzian rule, joined the political contest trying to win over the female voters. It competed with its rivals for the claim to include women in politics.

In Sušak, a broader hostility to women's political participation initially coexisted with a form of women's associationism aimed at fighting for wider political representation by insisting on the role of education. The latter could have emancipated the Yugoslav population within the international arena as much as the female components of local society. In this way, both would have been able to overcome a condition of subalternity.

Beyond the issue of political participation, female representations in the local press allow us to analyse not only women's roles, but also the relations between the sexes and the intersection between gender aspects and political and social identities, in a context of sudden change that called for new power balances, now that the war had called into question the old ones. While it is undeniable that certain representations of women broke with the past, such as those of women's participation in political violence, traditional images of women and gender relations were equally present in all local newspapers: the mother figure, the fallen soldier's widow, the feminisation of territorial conquests and the enemy's threat to female honour, representing the nation. If contrasting representations of the female component initially coexisted in the local press, soon those images that were more strongly tied to traditional roles started to prevail.

Another important rupture with the past resides in the city's different representations. External sources adopt patriotic terms to idealise Fiume, granting 
it a transgressive aura of which Dannunzianism was a symbol, whereas the local press linked the disorder caused by the frenetic military events to gender relations and public morality, even if it conveyed the image of a secular and cosmopolitan city where women enjoyed greater autonomy compared to the surrounding areas. If the pro-Yugoslav or autonomist press sources highlighted the city's - and, accordingly, women's - oppression following the arrival of thousands of paramilitary soldiers, national stereotypes were equally conditioned by a gender dimension.

Moreover, as the years passed women's presence progressively thinned out in all newspapers. Women were gradually marginalised from the political scene and deprived of the - universal and partial — right to vote that they had previously managed to obtain, whereas appeals for political participation started to be directed at an exclusively male audience. After 1923-24, the normalisation process coincided with a period of full integration into two national states - the Kingdom of Italy and the Kingdom of SCS - neither of which kept his promises with regard to participation as it had been theorised within the representative national movements. ${ }^{116}$

In Fiume, women's participation gradually decreased, especially with the city's integration into fascist Italy, which further deprived women of the right to vote - what is more, women did not vote after 1921. Some of the women who had made specific efforts in favour of annexation to Italy continued to fill honourable positions, and accounts of women's engagement in military style did not vanish instantly. Thus, during the commemoration of Fiume's annexation to Italy, Elisa Majer Rizzioli — founder of the female Fasci - recalled the role played by the women of the Nascimbeni family: although "less fortunate" than the family's male members who had died for the cause, ${ }^{117}$ they were allegedly wounded during battles in which they had fought "manly". ${ }^{118}$ Furthermore, the Nascimbeni women were said to have participated in the battles of March 1922, which resulted in the fascist coup against the municipal council largely consisting of autonomists — that had been elected in April 1921. ${ }^{119}$

A good example of the new regime's difficulty in mobilising the female component of society was an incident that involved the local female Fascio, created in 1925 to focalise women's energies towards an acknowledged social

${ }^{116}$ E. Schiavon, The women's suffrage campaign, p. 51; I. Ograjšek Gorenjak, Opazne iluzije, pp. 112-114.

${ }^{117}$ In 1921, Glauco Nascimbeni was among the victims of the repression - by Italian contingents - of a demonstration that claimed the supremacy of Fiume over the harbour area in Baross, which had been assigned to the Kingdom of SCS.

${ }^{118}$ Elisa Majer Rizzioli, Coi fratelli fiumani, "Per l'annessione di Fiume. Edited by the Associazione legionarie di Fiume e Dalmazia”, 27 January - 2 March 1924.

${ }^{119}$ Ernesto Cabruna, Fiume 10 gennaio 1921-23 marzo 1922, Montegiorgio, Tip. C. Zizzini, 1933, p. 70. 
role: care work. ${ }^{120}$ The Tuscan Ersilia Marassi de' Pazzi was placed at the head of this organisation. ${ }^{121}$ Three years after its creation, though, the results turned out to be scarce, with only 405 members in the entire Kvarner province. ${ }^{122}$ According to local authorities, "[t]he propaganda and expansion of the female organisation is difficult and slow, and it is unnecessary to indicate the causes, which are - if I may be so bold — principally determined by sex". ${ }^{123}$ Nonetheless, it must be noted that the organisation engaged in childcare activities and also initiatives for foreign women, albeit for propagandist purposes. ${ }^{124}$

As the historian Victoria de Grazia has underlined, while being subsumed within a patriarchal framework, the fascist women's associations broadened their action range beyond the family unit; in some cases, they allowed women to introduce their own contents into the regime's institutions, and it would therefore be wrong to downplay their importance. ${ }^{125}$ Still, in the absence of direct accounts from the local women involved it remains difficult to assess the full meaning of this experience.

The case of the women's associations of Sušak followed a very similar course. Although they remained active in subsequent years, they completely abandoned all political claims and focused their attention on charity activities. One of the JŽDD committees was still active in 1925, when a female artisan school from Belgrade visited Sušak. ${ }^{126}$ In that same year, Pavica J. Kaftanić gave a pan-Slavist concert of "Slav, Russian and Czechoslovakian arias", and donated the proceeds to the Pupils' Canteen (Djačka menza) and Children's Shelter (Sklonište) - two institutions that the pro-Yugoslav associations had founded after the end of the war. ${ }^{127}$ Throughout the years, the most important women's association turned out to be the Society of Serbian Sisters [Kolo srpskih sestara, hereafter KSS]. Its very name revealed a reference to Serbian national identity - compared to the Yugoslavist and democratic-sounding JŽDD — and it had an elitist character, with Vidović again leading the association. Delfa Ivanić, who returned to the city at the end of 1925 , recalled its celebration of the day of Saint Sava, the founder of the Serbian Orthodox Church. ${ }^{128}$

${ }^{120}$ R. Pickering-Iazzi, Mothers of invention, p. XVI.

${ }^{121}$ Giuseppe Parlato, Mezzo secolo di Fiume: economia e società a Fiume nella prima metà del Novecento, Siena, Cantagalli, 2009, p. 121.

122 The province comprised of a section of the coast and of the hinterland, the latter mostly inhabited by a Slovenian-speaking population, up to the current area of Ilirska Bistrica (then Villa del Nevoso).

${ }^{123}$ Quarterly report on the political and economic situation (December-February 1928), pp. 1-2, in DARI, Riječka prefektura, k. 6.

${ }_{124}$ B. 675, Archivio centrale dello Stato, Partito Nazionale Fascista, Direttorio Nazionale, Servizi Vari Serie I.

${ }^{125}$ V. de Grazia, Le donne nel regime fascista, pp. 30-31.

${ }^{126}$ Mjesne i društvene vijesti, "SNL", 22 April 1925, p. 3.

${ }^{127}$ Mjesne i društvene vijesti, "SNL", 22 and 26 November 1925, p. 3.

${ }^{128}$ J. Milanović, Delfa Ivanić, pp. 224-225. 
If by 1929 the JŽDD - in which many women teachers had played a prominent role — still counted 200 members, ${ }^{129}$ the KSS, ${ }^{130}$ whose council was primarily composed of housewives, totalled only 26 members. Strongly supported by local and central authorities, the KSS would maintain a constant presence in Sušak's associationism in the following years, underscoring its proximity to the Royal House of Belgrade by electing the first lady-in-waiting Mirka Grujić president. ${ }^{131}$

Notwithstanding the initial moment of mobilisation, the new political structures of the Kingdom of Italy and the Kingdom of SCS (later Yugoslavia) offered few and limited possibilities for political engagement even to those women who had invested in the process of building new post-war societies; and many also remained excluded. These were women who did not identify with the national (and nationalist) options and with the majority parties, who did not have the financial power to participate: women to whom the urban environment of the Kvarner region was not the harbour of opportunities the city had represented prior to 1914, in those years of extraordinary economic development.

${ }^{129}$ Democratic Association of Yugoslav Women in Sušak to the Commission of the Royal Police, 24 January 1929 in DARI, Gradsko poglavarstvo, k. 528, fasc. Žensko demokratsko udruženje u Sušaku 1922-1940.

${ }^{130}$ Jelena Savić, Kolo srpskih sestara - Odgovor elite na žensko pitanje, "Glasnik etnografskog muzeja u Beogradu", 2009, pp. 124-126.

${ }_{131}$ Royal prefecture of Fiume to the Police Commissioner, 6 May 1930, in DARI, Riječka kvestura, A3, k. 196. 